\title{
Az egészségegyenlőtlenségek csökkentésének nehézségei
}

\section{Problems in reducing health inequalities}

\author{
Szerző: Csizmadia Péter $\square$ \\ Nemzeti Egészségfejlesztési Intézet
}

Beküldve: 2016.02.07.

doi: $10.24365 /$ ef.v58i1.138

\begin{abstract}
Absztrakt: A cikk definiálja és különbséget tesz az elkerülhető egészségegyenlőtlenségek, és az igazságtalan és megelőzhető egészségbeli méltánytalanságok között, ismerteti az egészségegyenlőtlenségek főbb dimenzióit, amelyek mentén az egyenlőtlenségeket vizsgálni szokták a világ teljes népességén át, országok vagy államok, földrajzi különbségek, társadalmilag releváns csoportok, mint faj, nemzetiség, nem, képzettség, jövedelem, foglalkozás és egyebek alapján. Az írás különböző elméleteket mutat be, amelyek megkísérlik, hogy magyarázatot adjanak egyrészt az egészség csoport szintű eltéréseire, másrészt a szocioökonómiai egyenlőtlenségek tartós fennmaradására még a fejlett nyugat-európai jóléti államokban is.
\end{abstract}

Kulcsszavak: egészségegyenlőtlenségek, egészségbeli méltánytalanságok

\begin{abstract}
This article defines and distinguishes between unavoidable health inequalities and unjust and preventable health inequities. It describes the dimensions along which health inequalities are commonly examined, including across the global population, between countries or states, and within geographies, by socially relevant groupings such as race/ethnicity, gender, education, income, occupation, and more. We show different theories attempt to explain group-level differences in health and the persistence of socioeconomic inequalities in health even in the highly developed "welfare state"' of Western Europe.
\end{abstract}

Keywords: health inequalities, health inequities

\section{AZ EGÉSZSÉGEGYENLŐTLENSÉGEK JELENTŐ- SÉGE}

Nemzetközi fórumokon az utóbbi években ismét fokozott figyelem irányul az egészségegyenlőtlenségek felé. A növekvő figyelem egyfajta szemléletváltozásnak köszönhető, ugyanis a gazdasági növekedés és az egészség közötti kapcsolat egyre nyilvánvalóbbá vált. Elemzések bizonyították, hogy az 1980-as és 1990-es években végbement gazdasági fellendülés nem vezetett a jólét általános növekedéséhez, ám a társadalmi egyenlőtlenségekben jelentős különbségek keletkeztek. A kialakuló társa- dalmi polarizáció, dezintegráció, politikai szélsőségek erősödése nemcsak az egyének jólétét, biztonságát, közérzetét veszélyeztetik, hanem a hosszú távú gazdasági fejlődést is. A demográfiai változások, a gazdaságilag aktív népesség arányának csökkenése is aláhúzta a gazdasági változás emberi tényezőinek fontosságát. Elismerést nyert az az álláspont, hogy az egészségi állapot az egyének teljesítményére, ezáltal a gazdasági növekedésre is hatást gyakorol. ${ }^{1}$

A nagy egészségegyenlőtlenségek súlyosan veszélyeztetik az adott ország gazdasági teljesítményét, 
hosszú távú fejlődését, ezért ezeknek az egyenlőtlenségeknek a csökkentése alapvető fontosságú a társadalmak számára.

Jelen cikkben, a nemrégiben megjelent releváns tanulmányok alapján próbálom összefoglalni az egészségegyenlőtlenségekkel kapcsolatos metodológiai, elméleti aspektusokat, igyekszem kísérletet tenni az alapvető fogalmak tisztázására és a legfontosabb elméletek bemutatására, ezzel is elősegítve a téma további kutatását. ${ }^{2,3}$

Az egészségegyenlőtlenségek sokféle értelmezése és megnevezése használatos, főként amiatt, hogy különböző tudományágak képviselői eltérő megközelítéssel vizsgálják e jelenséget. Az angol és amerikai szakirodalomban legtöbbször health variation, health disparity, health diversity kifejezéssel jelölik az egyes társadalmi csoportok egészsége között megfigyelhető különbségeket. Az ilyen eltéréseket egészségkülönbségeknek nevezzük. E fogalom szakszerű meghatározása tehát: egyes társadalmi, demográfia vagy földrajzi lakosságcsoportok egészségében jelentkező egy vagy több szisztematikus különbség, amelyek egy része biológiai okokra, mint például a női és férfi hormonális rendszer eltéréseire vezethetők vissza. Az egészségkülönbség szemléltetésére jó példa a nők és férfiak várható élettartama között tapasztalt eltérés.

Azokat az egészségkülönbségeket, amelyek megelőzhetőek és szükségtelenek, megfelelő eszközök alkalmazásával elkerülhetők, illetve egy adott társadalomban igazságtalannak tartanak angol szakkifejezéssel health inequitynek nevezzük. Fordítására a méltánytalanság, az igazságtalanság, egészségben megnyilvánuló esélyegyenlőtlenség elnevezések használatosak.

Az egészségegyenlőtlenségek fogalmát (health inequalities) így definiálja a fenti hivatkozott tanulmány: minden egyének vagy csoportok között egészségben megnyilvánuló valamilyen mutatóval mérhető egyenlőtlenség.

A fő különbség a két meghatározás között, hogy az utóbbi mennyiségi egyenlőtlenségre utal, míg az első morális ítéletet is tartalmaz, hogy az egyenlőtlenség erkölcsileg rossz.

Az egyenlőtlenségek megléte nem csak morális kérdés, hiszen jelentős gazdasági hatásuk is van. 2003 és 2006 között a faji vagy etnikai alapú egészségegyenlőtlenségeknek közvetlen gazdasági költségeit az USA-ban 230 milliárd dollárra becsülték. Kutatások szerint az egészségegyenlőtlenségek hátrányosan befolyásolják a dolgozók termelékenységét.

\section{AZ EGYENLŐTLENSÉGEK OPERACIONALIZÁLÁSA}

\section{Csoport és egyén}

Két fő megközelítési mód létezik az egyenlőtlenségek vizsgálatára: a népességen belüli, illetve a népességek közötti összehasonlítás. Általában az egészségi állapot eltéréseinek kutatása csoportok összehasonlításával történik.

A WHO a csoport szintű egészségegyenlőtlenségek vizsgálatában a releváns társadalmi csoportokat definiálja, amelyeket az angol PROGRESS betűszóval szokás összefoglalni: Place of residence, Race/ethnicity, Occupation, Gender, Religion, Education, Socioeconomic status, and Social capital/resources, azaz lakóhely, etnikum, foglalkozás, nem, vallás, iskolázottság, társadalmi-gazdasági helyzet, társadalmi tőke.

Az alternatív megközelítési mód az egyéni különbségekre fókuszál, leírva a terjedelmet vagy a szórást egy adott mutató esetében a teljes populációban. Ez a módszer eltekint a csoportképzéstől egyetlen eloszlásba vonva össze a minta tagjait. A kutatók a globális jövedelmi egyenlőtlenségek vizsgálatakor használják ezt a metódust, hogy például kiemeljék a szegények relatíve jó vagyoni helyzetét a gazdag országokban, a szegény országokban élő jómódúakhoz képest.

Az átgondolt csoportképzés alapvető fontosságú az egyenlőtlenségek vizsgálatakor. Vagy azt gondoljuk, hogy az egészségi állapot függ a társadalmi erőforrások bizonyos szintjétől, vagy azt feltételezzük, hogy a társadalmi különbségek inkább dózis és reakció alapúak. A társadalmi lejtő az egészségben ott létezik, ahol a társadalmi erőforrások növekvő mennyisége, mint az oktatás vagy jövedelem összhangban vannak a jobb egészség szintjével, egyfajta dózis és reakció kapcsolatként.

A kapcsolat az oktatás és az egészség között olyan, hogy a magas és alacsony oktatási szint esetén is, a további oktatásban eltöltött évek, összhangban vannak az elért jobb egészséggel. Amennyiben a társadalmi lejtő helyett az egészségnek inkább küszöbhatása van, az figyelhetô meg, ha valaki nem vesz részt a középfokú vagy magasabb szintű képzésben 
az rosszabb egészséggel jár, de az oktatás és az egészség nem kapcsolódott azoknál, akik befejezték a középfokú- vagy annál magasabb iskolát. Például ezen küszöbhatás szerint nem várjuk, hogy az egyetemi diplomával rendelkezők egészségesebbek, mint a főiskolai végzettséggel rendelkezők.

Brit köztisztviselők 1967-ben kezdődött követéses vizsgálata, a Whitehall kutatás eredményei azt mutatták, hogy a hivatali ranglétrán elfoglalt pozíció fordított összefüggésben volt a halandósággal és számos krónikus betegséggel. ${ }^{4}$

\section{Abszolút vagy relatív egyenlőtlenség}

Az abszolút szegénységi mérőszámok közé tartozik a létminimum tételes meghatározásának módszere, nevezetesen azon javak és szolgáltatások számbavétele, amelyek a létfenntartáshoz szükségesek. A fogyasztói kosárral meghatározott szegénységi mérőszám szerint a társadalomban azok az egyének, illetve családok tekinthetők szegénynek, akiknek a jövedelme nem teszi lehetővé a létminimumként elismert szükségletek kielégítését. Ez a küszöb országonként, évenként, háztartás mérettől függően változhat.

A relatív szegénység a jövedelem eloszlása alapján kerül meghatározásra egy adott népességen belül. Az abszolút szegénységi megközelítések folyamatosan háttérbe szorultak, és helyüket a relatív típusú szegénységmérési módszerek vették át. Ezen mérési módszerek közé tartoznak a szegénységi mérők (szegénységi ráta, szegénységi rés, szegénységi rés aránya) és egyenlőtlenségi mutatók (Robin Hood-index, a Gini-mutató, Sen-index). A relatív szegénységi mérőszámok közül a legegyszerübbek a szegénységi ráták arra adnak választ, hogy az össznépességnek mekkora hányada, hány százaléka esik a szegénységi küszöbérték alá.

Például, aki kevesebbet keres, mint az egy före eső jövedelem 30\%-a az szegénynek tekinthető, ami azt sugallja, hogy a szegénységi küszöb változik, ahogy az átlagos jövedelem növekszik.

Bizonyos lakossági felmérések esetén a megkérdezett háztartások maguk is nyilatkoznak arról, mekkora összeget tartanak szükségesnek egy, az övékével azonos összetételű háztartás „nagyon szúkös megélhetéséhez". E szubjektív összegek egy főre vagy egy fogyasztási egységre jutó súlyozott átlaga alapján definiálható a szubjektív szegénység.

Földrajzi egyenlőtlenségek

A földrajzi elhelyezkedés fontos szerepet tölt be az egészségi állapot alakulásában. A térbeli és a helyi különbségtétel segít annak a jobb megértésében, a földrajzi tényezők hogyan befolyásolhatják az egészséget, mint a távolság vagy közelség, az egészség kockázati és támogató tényezőinek a térbeli eloszlása, amelyek az egyén pontos pozíciójától függnek. A levegő szennyezettség, amely súlyosbítja az asztmás tüneteket, lehet példa térbeli rizikó tényezőre. A hulladéklerakó közelsége, az egészségügyi ellátó helyek távolsága, a földrajzilag meghatározott rizikó- és támogató hatásokra példák. Ezzel ellentétben a hely a tagságra utal politikai, vagy adminisztratív egységekben, mint egy iskolai körzet, városok vagy államok. Számos kormányzat folytat olyan programokat, szakpolitikákat, amelyek befolyásolják az egészséget, mint például az adópolitika. Ilyen esetekben a hatás nem a lakó földrajzi helyzetétől függ, hanem inkább az adott politikai vagy adminisztratív egységben betöltött tagsági viszonyától.

Az egyenlőtlenségek megértése: ok-okozati hatások

Amikor a kapcsolatot vizsgáljuk két változó között, mondjuk a foglalkozás és a vérnyomás között, gyakran egyértelművé válik, hogy egy harmadik változót is figyelembe kell venni. Ebben az estben a jövedelem lesz, amely kapcsolatot teremt a két változó között. A munkahely meghatározhatja a jövedelmet, amely pedig hat a vérnyomásra akár úgy, hogy a személy vehet egészségesebb élelmiszert, vagy jobb ellátáshoz juthat. Ha ez így van, amikor be kívánunk avatkozni a vérnyomáscsökkentés érdekében, akkor elégséges készpénzbeli transzfereket alkalmazni a vérnyomás normalizálására, és a munkafeltételeket nem szükséges megváltoztatni. Azonban, ha a jövedelem növelése ellenére úgy találjuk, hogy a vérnyomás továbbra sem kívánatos mértékú, akkor a foglalkozás egyéb módon is hat, magyarán a jövedelem csak részben magyarázza a foglalkozás és vérnyomás kapcsolatát. A kutatókat további vizsgálatokra ösztönzi, hogy a munkahelyi stressz vagy egyéb munkahelyi feltételek miként befolyásolják az egészséget. 


\section{Az egyéni választás}

A szelekció egy újabb alapvető része az egészségegyenlőtlenségek megértésének. A szelekció arra a tényre utal, hogy az emberek hajlamosak magukat elhelyezni lakóhely, és egyéb társadalmi csoportok alapján. Például azok, akik értéknek tekintik a fizikai aktivitást valószínúbb, hogy gyaloglásra alkalmas területre költöznek, míg az ülő életmódot folytatók lehetséges, hogy az autós közlekedéstől jobban függő elővárosba keresnek lakhelyet. A rendelkezésre álló adatok alapján, ha a lakókörnyezet milyensége hatást gyakorol a fizikai aktivitás szintjére, feltehetjük a kérdést, hogy a megfigyelt összefüggés mennyire oksági kapcsolatokra utal, illetve mennyire a lakókörnyezettel összefüggő önszelekció. A szelekció esetenként magyarázatul szolgál oktatási, foglalkoztatási és gyakran faji, nemzetiségi különbségekre az egészségben. Például egyesek érvelhetnek amellett, hogy a SES (socioeconomic status, szocioökonómiai státusz) és az egészség közötti összefüggés a szelekció eredménye, azt állítva, hogy a genetikailag magasabb rendű egyének valószínúleg jobb egészségűek és nagyobb az IQ-juk, így magyarázva, hogy a magasabb iskolai végzettséggel és magasabb jövedelemmel rendelkezők általában egészségesebbek. Az oksági kapcsolatok feltárását célzó kutatások általában elvetik ezt a fajta magyarázatot, az azonban biztos, hogy a foglalkoztatás, a jövedelem, a diszkrimináció és a deprivált lakókörnyezet jelentős hatást gyakorol az egészségre.

\section{A kontextuális és kompozit hatások}

Amikor a szelekció a földrajzi egészségegyenlőtlenségek forrása, a kutatók általában igyekeznek elkülöníteni a kontextuális és kompozit hatásokat. A kontextuális hatások utalhatnak a lakókörnyezet vagy egyéb nagyobb egységek hatására, míg a kompozit hatásokon egyszerűen a lakó- vagy egyéb környezeti jellemzőket értjük, olyan különbségeket, amelyek egy adott egység társadalmi összetételéből származó hatása révén befolyásolják az egészségegyenlőtlenségeket.

Iskolai osztályok, iskolák, államok, kórházak egyéb intézményi egységek gyakorolhatnak kontextuális hatást, de ide sorolhatjuk a szakpolitikákat, infrastrukturális forrásokat, intervenciókat is.
Kompozit és kontextuális hatások közti különbségtétel kiemelt fontosságú az oksági következtetések szempontjából. Ha tudjuk, hogy az egyenlőtlenségek léteznek kontextustól függetlenül, az még nem mond semmit arról, hogy miért léteznek: A szegény lakókörnyezet növeli a megbetegedések kockázatát? Azután hogy figyelembe vettük az egyéni szint rizikó tényezőit, még vannak eltérések az egészégi állapotban a szegény és jómódú lakókörnyezet között? Továbbá a lakókörnyezet depriváltságának ugyanaz a hatása minden társadalmi csoportra, vagy vannak sajátos kockázatok? A koncentrált szegénységnek és egyéb más kontextuális jellemzőnek lehet, nem csak a közösség általános egészségére van hatása, hanem a társadalmi csoportok közötti egészségegyenlőtlenségekre is.

Kompozit hatás gyakorolhat, ha egy új ellátó központ építése a környéken élő nagyszámú krónikus beteget magához vonzza.

\section{ÉLETÚT MEGKÖZELÍTÉS}

A korai életkor és a magzati körülmények hatással lehetnek a későbbi egészségre a további életúttól függetlenül, így létrehozva az egészségegyenlőtlenségeket. Vannak különösen kritikus és érzékeny fejlődési szakaszok, amelyek döntően befolyásolják az egészséget, és amelyeknek hatása nem visszafordítható. Például a serdülőkori egészségtelen táplálkozás a csonttömeg fejlődésének időszakában, az egyén számára növeli a csonttörés kockázatát a későbbi életszakaszokban. A korai életkorban kialakult szokások hatást gyakorolhatnak az egészséggel kapcsolatos választásokra. A nem megfelelő fizikai aktivitás a gyermekkorban befolyásolhatja a felnőttkori testedzési szokásokat.

Amikor a társadalmi mobilitás szintje alacsony és a társadalmilag marginalizálódott csoportoknak korlátozott lehetőségeik vannak a lakóhelyük megválasztására, az életkezdet különösen erőteljes a későbbi egészségegyenlőtlenségek magyarázatában. Például azokban a társadalmakban, ahol küzdenek a szegénység nemzedékek közötti átörökítésével, vagy a marginális csoportok lakóhelyi elkülönülése történelmileg megfigyelhető, valószínú, hogy a személyek jelenleg fennálló társadalmi egészségkockázatai korábbi társadalmi meghatározottságra vezethetők vissza. 
A kutatóknak tisztában kell lenni vele, hogy a hoszszan tartó kitettség, még akkor is, ha távolinak tűnik, mint a szülő foglalkozása, vagy a gyermekkori lakókörnyék, hasznos magyarázó tényezője lehet az egészségi állapotnak. A longitudinális és trend ada- tok szintén fontosak az okozati összefüggések megértésében az egészség és a társadalmi környezet között. Az életút megközelítés vázlata az 1 . ábrán látható.

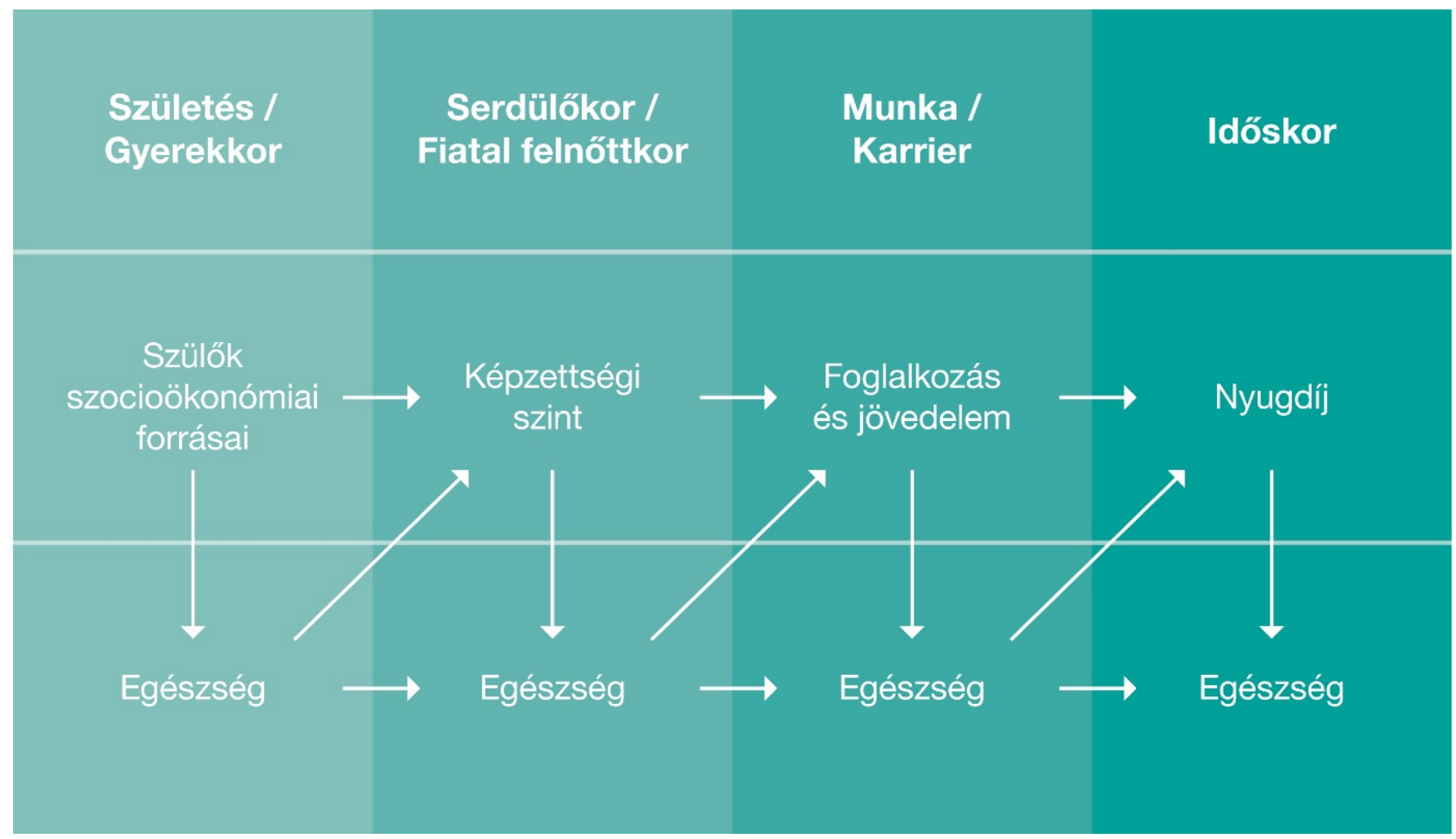

Forrás: MC Arcaya et al. ${ }^{2}$

\section{MAGYARÁZATOK AZ EGÉSZSÉGEGYENLŐTLEN- SÉGEKRE}

A magyarázatok egyik csoportja az anyagi tényezőkre hívja fel a figyelmet az egészségegyenlőtlenségek keletkezésében. Az anyagi tényezők magukba foglalják többek közt a táplálékot, a lakhatást, a szennyezettséget és egyéb fizikai kockázatokat, amelyek az egészségi állapotot befolyásolják. Az abszolút források mérőeszközei, például az abszolút jövedelem, hasznosak lehetnek az anyagi depriváció szerepének megállapításában.

A magyarázatok második csoportja a pszichoszociális tényezők szerepére mutat rá. Ide tartozhatnak a társadalmi kirekesztettség, a diszkri- mináció, a stressz, az alacsony társadalmi támogatottság és egyéb társadalmi negatív tapasztalatokra adott pszichológiai reakciók. A negatív pszichológiai állapot hatással van a fizikai egészségre a biológiai stresszválasz aktiválásával, amely például magas vérnyomást okozhat.

A magatartásbeli eltérések szintén gyakran idézett tényezők, amelyek hozzájárulnak az egészségegyenlőtlenségekhez. Például a magatartáshoz kapcsolódó magyarázatok az egészségegyenlőtlenségeket a táplálkozásbeli különbségeknek, a dohányzás gyakoriságának vagy a rákszűrésen való részvételnek, a társadalom különböző csoportjaiban való eltérésének tulajdoníthatják. Míg az egészségmagatartás gyakran eltérő a csoportok között, az ökoszociális és 
szocioökológiai koncepciók arra ösztönzik a szakembereket, hogy feltegyék a kérdést, milyen tényezők okozzák ezeket a különbségeket. Abban az esetben, ha például a dohányzásban található különbségek az egyenlőtlen oktatási lehetőségekből, a pszichoszociális rizikó tényezők méltánytalan eloszlásából, a célzott marketingből adódnak, az egészségegyenlőtlenségeket az egészségmagatartásra visszavezetni korlátozott haszonnal jár.

A negyedik típusa a magyarázatoknak a biológiailag meghatározott egészségrizikófaktorok, amelyek, eltérőek a társadalmi csoportokban vagy különböznek az egyénekben, a népességben. A biomedikális magyarázatoknak megvan az a gyengesége, ahogy az egészségmagatartásból levezetett társadalmi egyenlőtlenségeknek az egészség esetében, hogy nem ad választ arra, hogy a biológiai kockázatok miért eltérőek a teljes populációban.

Az a paradox helyzet állt elő, hogy a szocioökonómiai eredetű egészségegyenlőtlenségek még a legfejlettebb nyugat-európai jóléti államokban is fennmaradtak a jóléti államok kiépülése során, bizonyos mértékig tovább szélesedtek, és nem csökkentek a bőkezű jóléti intézkedések ellenére sem.

Mackenbach tanulmánya a halandósági adatok elemzéséből kiindulva próbálja áttekinteni az egészségegyenlőtlenség fennmaradását magyarázó elméleteket, és kísérletet tesz ezek szintézisére. Az alábbiakban e cikk főbb megállapításait mutatom be.

- A jóléti államoknak nem sikerült az egyenlőtlenségek kiküszöbölése az anyagi és nem anyagi forrásokhoz való hozzáférésben, amelyek még mindig jelentősek.

- A generációk közötti fokozottabb mobilitás miatt az alacsony szocioökonómiai státuszú csoportok homogénebbeké váltak a rossz egészséggel összefüggő személyes jellemzők tekintetében.

- A jelenlegi epidemiológiai helyzetben, a fogyasztáscentrikus magatartás a rossz egészégi állapot legfontosabb meghatározójává vált, az immateriális javakhoz való hozzáférés a magasabb társadalmi státusz révén nagyobb előnyökkel jár.

Bizonyítékok állnak rendelkezésre arról, hogy a jó- léti állam sikerrel járult hozzá az egyenlőtlenségek csökkentéséhez a jövedelem, a lakhatás, az egészségügyi ellátás és egyéb társadalmi és gazdasági területen, ennek ellenére az egyenlőtlenségek kiküszöbölése nem valósult meg. Hosszú távú idősoros adatok az egészségegyenlőtlenségekről nem állnak rendelkezésre, de angol adatok az sugallják, hogy a halandóságban megnyilvánuló egyenlőtlenségek 1950-ig szűkültek, majd utána szélesedtek. Ha az 1920-1980 közötti időszakot vesszük, amikor az európai jóléti államok kiépültek, a csökkenés tendenciája a halandóságban csak a korai szakaszban érvényesült. A halandóságban megfigyelhető egyenlőtlenségek a 21. században tovább folytatódtak minden olyan országban, ahonnan elérhetőek adatok. Az elmúlt 3-4 évtizedben az egyenlőtlenségek növekedtek a halandóság tekintetében relatív, esetenként abszolút értelemben számos nyugat-európai országban. Ez a változás már jóval a jóléti intézkedések kilencvenes években való „visszavágása” előtt megkezdődött.

A paradox helyzet még zavarba ejtőbbé válik a kapcsolat hiánya, a kiterjedt vagy intenzív jóléti intézkedések, illetve az általuk elért hatás között az egészségegyenlőtlenségek szempontjából. Összehasonlító tanulmányok szerint a szocioökonómiai egyenlőtlenségek a mortalitásban és a morbiditás nem kisebbek azokban az országokban, ahol relatíve univerzális és bőkezú jóléti politikát folytattak, például a skandináv országokban, azokhoz a dél-európai országok képest, ahol sokkal inkább a család volt a jóléti állam egysége, illetve Nagy-Britanniához képest, ahol jóval liberálisabb megközelítés érvényesült.

Az 1. táblázat és a 2. ábra illusztrálja, hogy NyugatEurópában mind a relatív, mind az abszolút egyenlőtlenségek a teljes mortalitásban elsősorban délen Torino és Madrid környékén a legalacsonyabbak. Ez elsősorban a kardiovaszkuláris és rákos betegségek okozta halálozásban mutatkozó kismértékű egyenlőtlenségeknek „köszönhető”. Svédországot relatíve kisebb egyenlőtlenségek jellemzik a mortalitás tekintetében, de Norvégiában ezek jelentősen nagyobbak, mint a dél-európai vagy az angol/walesi példák, részben a dohányzás okozta halálozásban felfedezhető nagy egyenlőtlenségek okán. 
1. táblázat: A halálozási többlet a legalacsonyabb iskolázottságúak között az 1990-es években (Az egyenlötlenségek lejtő indexe életkorra korrigált halálozás évenként 100000 személyévenként)

\begin{tabular}{|c|c|c|c|c|c|c|}
\hline & $\begin{array}{l}\text { Minden } \\
\text { ok }\end{array}$ & Rák & $\begin{array}{l}\text { Szív- és ér- } \\
\text { rendszeri }\end{array}$ & Sérülés & $\begin{array}{l}\text { Alkohol } \\
\text { okozta }\end{array}$ & $\begin{array}{c}\text { Dohányzás } \\
\text { okozta }\end{array}$ \\
\hline \multicolumn{7}{|l|}{ Férfiak } \\
\hline Svédország & 625 & 90 & 309 & 52 & 60 & 71 \\
\hline Norvégia & 980 & 169 & 434 & 70 & 62 & 166 \\
\hline Anglia/Wales & 862 & 225 & 401 & 19 & 28 & 241 \\
\hline Franciaország & 1044 & 333 & 232 & 109 & 196 & 204 \\
\hline Olaszország (Torino) & 639 & 232 & 140 & 23 & 63 & 177 \\
\hline Spanyolország (Madrid) & 530 & 181 & 38 & 26 & 75 & 170 \\
\hline \multicolumn{7}{|l|}{ Nők } \\
\hline Svédország & 381 & 73 & 172 & 8 & 15 & 39 \\
\hline Norvégia & 518 & 103 & 239 & 5 & 16 & 79 \\
\hline Anglia/Wales & 462 & 111 & 236 & 1 & 7 & 103 \\
\hline Franciaország & 375 & 50 & 130 & 36 & 30 & 17 \\
\hline Olaszország (Torino) & 197 & 15 & 94 & -3 & 8 & -4 \\
\hline Spanyolország (Madrid) & 51 & -76 & 56 & 7 & 3 & -24 \\
\hline
\end{tabular}

Forrás: Mackenbach ${ }^{3}$

2. ábra: Foglalkozási státusz szerinti halálozás férfiak között Angliában és Walesben (1920 és 1980 között)

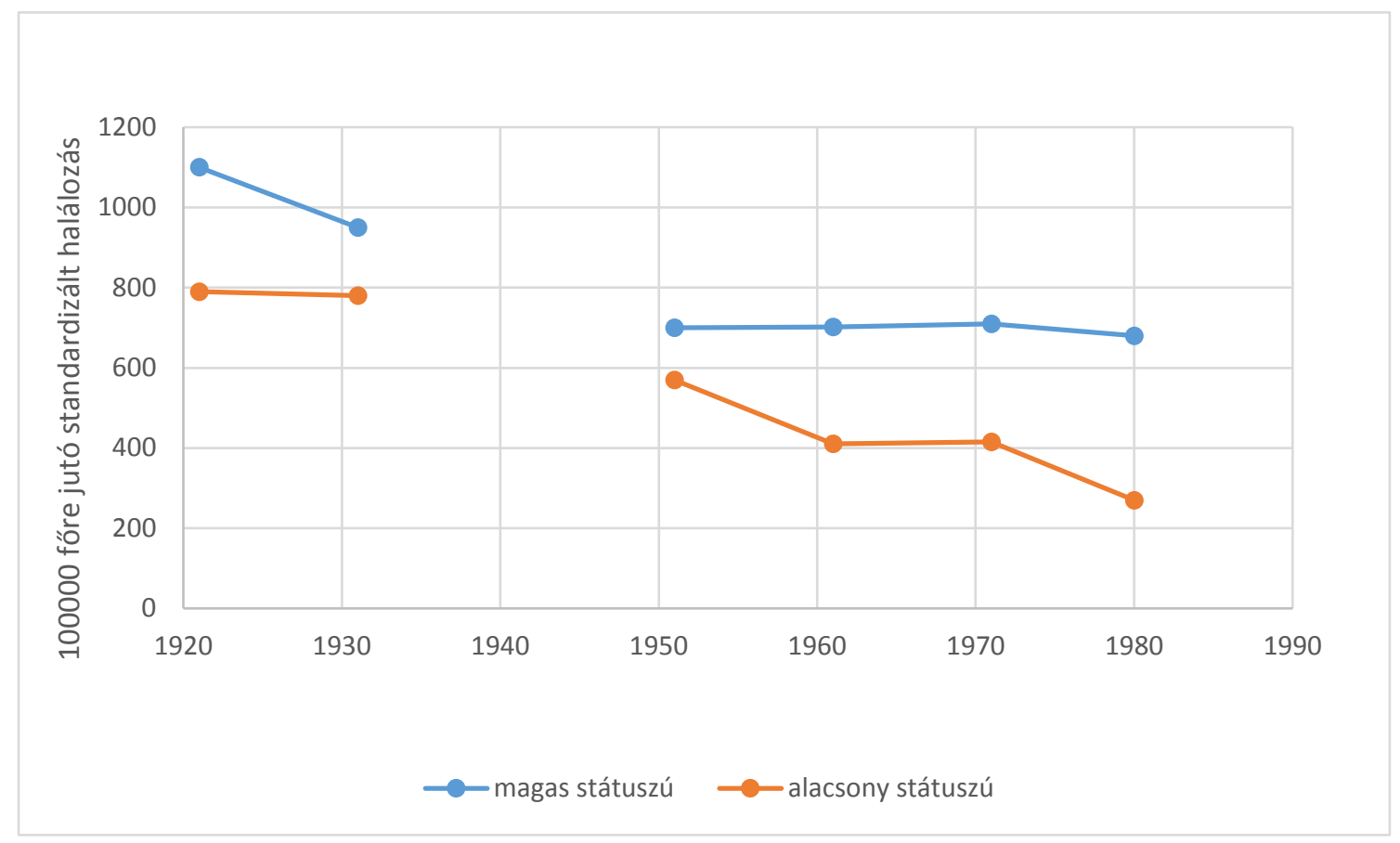

Forrás: Mackenbach ${ }^{3}$ 


\section{A társadalmi rétegződés három komponense}

A magyarázó elméletek közös nevezője, hogy aszocioökonómiai egyenlőtlenségeket a társadalmi egyenlőtlenségekből származtatják. Ebből az következik, hogy az egészségegyenlőtlenségek megértéséhez először a társadalmi rétegződést kell megérteni. A társadalmi rétegződésnek három összetevője van:

- társadalmi mobilitás mechanizmusai,

- források disztribúciója,

- társadalmi folyamatok, társadalmi változás: bizonyos források értékesebbekké válnak, mint mások.

Ez a három komponens szolgál az egészségegyenlőtlenségek alapjául.

\section{Magyarázó elméletek}

A matematikai szükségszerűség (artifact) elmélete szerint a relatív egyenlőtlenségek növekedése elkerülhetetlen, amikor az egészségeredmények összessége javul. Másképpen, nagyobb esély van rá, hogy a mortalitás és a morbiditás relatív kockázata magasabb, amikor az átlagos mortalitás és a morbiditás alacsonyabb, márpedig jelenleg a fejlett jóléti államokban ez a helyzet. Az elmélet ellenére bizonyítottnak tűnik, hogy nem szükségszerű a nagyobb egyenlőtlenség, amikor az általános eredmények javulnak.

Az alapvető okok elmélete úgy véli, hogy a társadalmi rétegződés következményei okozzák az egészségegyenlőtlenségeket és nem a közvetítő rizikó faktoroknak való kitettség (pl. dohányzás, pszichoszociális stressz, munkafeltételek). A szocioökonómiai státusz az egyént rugalmas erőforrásokkal ruházza fel, melyek közé többek között a tudás, a pénz, a hatalom, a presztízs és a társadalmi kapcsolatok tartoznak. Ezek segítenek a betegségek kockázatát és azok következményeit csökkenteni, függetlenül attól, hogy adott időben melyik számít relevánsnak. Az egészségkülönbségek a források egyenlőtlenségének és azok tartós fennmaradásának tulajdoníthatóak. Az egészségi állapotot javító közvetítő mechanizmusok - ilyen lehet például a citológiai mintavétel fejlődése (Pap-teszt elterjedése)
- ellenére, amelyek adott estben javítják a halandósági adatokat, a SES hatást az egészségegyenlőtlenségekre nem képesek kiegyenlíteni.

Az életút megközelítésben a felnőttkori egészség részben meghatározott a korai életszakaszokban megtapasztalt biológiai és társadalmi események által. A magzat „biológiai programozása” miatt fokozott sérülékenység feltételezhető a krónikus betegségek, például a diabétesz és a kardiovaszkuláris megbetegedések esetében. A kedvezőtlen társadalmi helyzethez és egészséghez kapcsolódó gyerekkori állapotok kezdetét jelenthetik a későbbi felnőttkori hátrányoknak. Az elmélet adós marad a válasszal azok esetében, akik már a jóléti állam ideje alatt születtek.

A társadalmi szelekció teóriát úgy interpretálhatjuk, hogy az egészségegyenlőtlenségek a társadalmi mobilitás során, az egészséggel összefüggő szelekció miatt alakulnak ki. Az egészségproblémák ugyanis lefelé irányuló mobilitáshoz vezethetnek (így egy közvetlen egészségi állapoton alapuló szelekciót eredményeznek). A felfelé irányuló mobilitás sokkal valószínúbb azok esetében, akik személyes jellemzői (például a big five ${ }^{1}$ személyiségmodellt alapul véve) támogatják a jó egészséget (közvetett egészségi állapoton alapuló szelekció).

A neo-materialista elmélet azt állítja, hogy az átlagos jólét növekedése és a bizonyos mértékű redisztribúció, más néven a jövedelmek újraelosztása ellenére az anyagi erőforrásokhoz való hozzáférés még mindig általános, az egyenlőtlenségek jelen vannak az anyagi forrásokhoz való hozzáférésben, amelyek egészségegyenlőtlenségeket generálnak, de nem magyarázza az egyenlőtlenségek növekedését.

A pszichoszociális elmélet kiemeli a pszichoszociális stressz jelentőségét, a társas támogatás hiányát, és a dolgok befolyásolásának az érzését (sense of control). A magasabb iskolai végzettséggel és/vagy jövedelemmel rendelkezők sokkal erősebb kontrollérzéssel rendelkezhetnek, amely kedvezően hat az egészségmagatartásukra. Ez a megközelítés nem magyarázza elfogadható módon az egészségegyenlőtlenségek szélesedését.

\footnotetext{
${ }^{11}$ A Big Five személyiségmodell lényege, hogy a különböző személyiségjellemzők öt faktorcsoportba sorolhatóak, amelyek a következők: extraverzió, barátságosság, lelkiismeretesség, érzelmi stabilitás, kultúra/intellektus.
} 
Az innováció egyenlőtlenségének az a következménye, hogy elsősorban a magasabb szocioökonómiai pozíciójúak képesek arra, hogy korábban alkalmazzanak új magatartásformákat, amelyeket az alacsony státuszúak csak később képesek követni. Az elmélet elfogadható magyarázattal szolgálhat az ideiglenes növekedésre az egyenlőtlenségekben, amikor nagyobb javulás lép fel a népesség körében, amely a magatartás változtatás eredménye. A fejlett országok az epidemiológiai átmenet abban a korszakában vannak, amelyben a civilizációs betegségek (kardiovaszkuláris betegségek, bizonyos rákos megbetegedések, balestek), amelyek a harmadik szakaszban dominálták, gyorsan visszaszorulnak. Ez részben az egészségügyi ellátás fejlődése, másrészről a magatartás változtatás eredménye (dohányzásról való leszokás, egészségesebb táplálkozás), ugyanis a jobb státuszúak korábban alkalmazzák az új magatartásformákat.

A kulturális tóke elmélete az egyenlőtlenségeket a szocioökonómiai csoportok között az attitúdben, a tudásban és a kompetenciában lévő különbségekkel magyarázza, amely különbségek a generációk között átöröklődnek.

A kulturális tőke fogalma magyarázatot ad a fogyasztás magatartásbeli egyenlőtlenségeire a különböző szocioökonómiai csoportok attitűd, tudás és képességek különbségei alapján, amelyek generációk között öröklődnek.

Az itt felsorolt elméletek szintéziseként az alábbi megállapításokat teszi a szerző:

1. Az alacsonyabb státuszú társadalmi rétegek egyre inkább olyan egyénekből állnak, akiknek a személyiség jegyei növekvő mértékben kockáztatják a rossz egészségi állapotot. Ez az évtizedekig tartó felfelé irányuló társadalmi mobilitásnak az eredménye, amely egyfajta szociális szelekcióként működött és homogénebbekké tette a társadalmi csoportokat a személyiségjegyek, mint pl. az alacsonyabb kognitív képesség tekintetében. Az intergenerációs mobilitás elsősorban a gazdasági változások miatt ment végbe, amely a közép- és felsőoktatás expanziójához vezetett és olyan mértékű volt, hogy az oktatási rendszer érdem alapúvá vált, ezáltal paradox módon hozzájárult az egyenlőtlenségek növeléséhez.

2. A fejlett jóléti államokban az epidemiológia fejlődés is eljutott az átmenet azon szakaszába, amikor az egészségi állapotban bekövetkező javulás nagymértékben a magatartás változtatás eredményétől függ. Ez növeli az immateriális tényezők, például a kulturális tőke és a személyiségjegyek jelentőségét (pl. kognitív képességek) az egészség szempontjából.

Ezen állítások alátámasztására a dohányzás visszaszorítására tett kezdeményezések említhetők. Azokban az országokban, ahol erőteljesebb intézkedéseket hoztak a dohányzás ellen, nagyobb valószínűséggel alakultak ki nagyobb szocioökonómiai egyenlőtlenségek a dohányzásban.

A cikk szerzőjének megállapításai röviden: a szociálepidemiológusok véleményével ellentétben nem egyértelmú, hogy az egyenlőtlenségek igazságtalanok (unfair), de bizonyosan tragikusak. Szomorú, hogy a szegényebbek rövidebb életet élnek, több időt töltenek rossz egészségben és valóban csalódást keltő, hogy az egészségegyenlőtlenségek, és következményeik annak ellenére, hogy komoly erőfeszítések történtek a csökkentésükre, továbbra is fennállnak.

Lényegi változást az egészségegyenlőtlenségekben csak radikálisabb újraelosztással lehet, vagy lehetett volna elérni, illetve a személyes, pszichoszociális és kulturális tényezők közvetlen befolyásolásával.

\footnotetext{
${ }^{1}$ Orosz É., Kollányi Zs.: Egészségi állapot, egészség-egyenlőtlenségek nemzetközi összehasonlításban Társadalmi riport 2016, szerkesztette: Kolosi T., Tóth István Gy.

${ }^{2}$ MC. Arcaya, AL Arcaya, SV: Subramanian Inequalities in health: definitions, concepts, and theories, Glob Health Action 2015, 8: 27106 - http://dx.doi.org/10.3402/gha.v8.27106

3 JP Mackenbach: The persistence of health inequalities in modern welfare states: The explanation of a paradox, Social Science \& Medicine 75 (2012) 761-769 doi:10.1016/j.socscimed.2012.02.031

${ }^{4}$ Reid, D. D., Bret, G. Z., Hamilton, P. J. S., Jarrett, R. J., Keen, H., and Rose, G. (1974). Cardiorespiratory disease and diabetes among middle-aged male civil servants. Lancet, 1, 469-473.
} 